\title{
Mild osmotic stress in intertidal gastropods Littorina saxatilis and Littorina obtusata (Mollusca: Caenogastropoda): a proteomic analysis
}

\section{Olga Muraeva ${ }^{1}$, Arina Maltseva ${ }^{1}$, Marina Varfolomeeva', Natalia Mikhailova ${ }^{1,2}$, and Andrey Granovitch ${ }^{1}$}

${ }^{1}$ Department of Invertebrate Zoology, Faculty of Biology, Saint Petersburg State University, Universitetskaya nab. 7-9, St. Petersburg, 199034, Russian Federation;

${ }^{2}$ Center of Cell Technologies, Institute of Cytology RAS,

Tikhoretsky prospect, 4, St. Petersburg, 194064, Russian Federation

Address correspondence and requests for materials to Arina Maltseva, arina.maltseva@spbu.ru

Citation: Muraeva, O., Maltseva, A., Varfolomeeva, M., Mikhailova, N., Granovitch, A. 2017. Mild osmotic stress in intertidal gastropods Littorina saxatilis and Littorina obtusata (Mollusca: Caenogastropoda): a proteomic analysis. Bio. Comm. 62(3): 202-213. https://doi. org/10.21638/11701/spbu03.2017.305

Author's information: Olga Muraeva, student, orcid.org/0000-0003-39322624, Researcher ID: B-6284-2018 Arina Maltseva, Associate Professor, orcid. org/0000-0003-1973-4728, Researcher ID: I-3631-2014; Marina Varfolomeeva, Assistant Professor, orcid.org/00000003-0887-8486, Researcher ID: D-10242013: Natalia Mikhailova, Associate Professor, orcid.org/0000-0003-16509330, Researcher ID: H-1811-2013; Andrey Granovitch, Dr. Sci., Professor, orcid.org/0000-0002-5203-104X Researcher ID: B-1264-2013

Manuscript Editor: Yegor Malashichev, Saint Petersburg State University, Russia;

Received: November 8, 2017;

Revised: November 24, 2017;

Accepted: November 25, 2017;

Copyright: ๑ 2017 Muraeva et al. This is an open-access article distributed under the terms of the License Agreement with Saint Petersburg State University, which permits to the authors an unrestricted distribution and self-archiving free of charge.

Funding: This work was supported by the Russian Foundation of Basic Research (project No 15-04-08210) and by a project of Saint Petersburg State University (project No 0.40 .491 .2017 )

Competing interests: The authors have declared that no competing interests exist.

\section{Abstract}

Salinity is a crucial abiotic environmental factor for marine animals, affecting their physiology and geographic ranges. Deviation of environmental salinity from the organismal optimum range results in an osmotic stress in osmoconformers, which keep their fluids isotonic to the environment. The ability to overcome such stress is critical for animals inhabiting areas with considerable salinity variation, such as intertidal areas. In this study, we compared the reaction to mild water freshening (from 24 to $14 \%$ ) in two related species of intertidal snails, Littorina saxatilis and L. obtusata, with respect to several aspects: survival, behavior and proteomic changes. Among these species, L. saxatilis is more tolerant to low salinity and survives in estuaries. We found out that the response of these species was much milder (with no mortality or isolation reaction observed) and involved weaker proteomic changes than during acute stress (freshening from 24 to $10 \%$ ), characterized earlier. The proteomic response of the second species, L. obtusata, was weaker ( $6 \%$ vs $10 \%$ of regulated proteins) than that of $L$. saxatilis and engaged a mostly different set of proteins. Among proteins potentially involved in adaptation to low salinity, we identified enzymes of energetic metabolism and antioxidant response, chaperones, proteins of extracellular matrix and cytoskeleton, ion channels and regulators of cell growth and proliferation.

Keywords: salinity adaptation, osmotic stress, proteomic analysis, intertidal molluscs, periwinkles, Littorina, 2D-DIGE

\section{Introduction}

Salinity is one of the most important factors for marine organisms, as it determines the geography of their ranges (Gunter, 1961). Salinity reflects the concentration of inorganic ions in water - primarily, ions of sodium, potassium, calcium, magnesium, chloride and sulfate (Robertson, 1941). These concentrations are more or less stable in the open ocean waters, but vary significantly in coastal area and estuaries among and within seasons (Redfield, 1958; Tabata, 1961; Hansen and Rattray, 1966; Berger, 1986).

Among marine invertebrate species, osmoconformers are most common these are organisms which maintain their inner fluids isotonic to the surrounding seawater. They retain their normal activities within a salinity tolerance range, while within resistance range they survive due to isolation reaction (Berger, 1986; Khlebovitch and Aladin, 2010). A profound deviation of salinity from the optimum range causes an osmotic stress in these animals, which adversly affects 
their functioning. At the cellular level, the stress boosts osmolyte concentration imbalance between cells and their environment, followed by a lesion of electrochemical potential of cellular membranes (Pierce, 1982; Stucchi-Zucchi and Salomao, 1998). Osmotic stress deeply affects various physiological processes, including those in nervous, immune and other systems (Stucchi-Zucchi and Salomao, 1998; Cheng et al., 2004; Bussell et al., 2008; Jauzein et al., 2013; Honorato et al., 2017). Considerable progress has been made in recent years in our understanding of the molecular background of salinity adaptation (An and Choi, 2010; Hoy et al., 2012; Lockwood and Somero, 2011; Zhao et al., 2012; Tomanek et al., 2012; Meng et al., 2013; Seveso et al., 2013; Carregosa et al., 2014; Muraeva et al., 2016; Gharbi et al., 2016; Yang et al., 2016; Yan et al., 2017). Nevertheless, greater knowledge about the physiological mechanisms of adaptation to salinity variation is still needed, especially in regard to intertidal invertebrates, which deal with osmotic stress throughout their lives.

The family Littorinidae includes a set of widely distributed species which are important members of intertidal communities of seacoasts around the world. During the last decades, Littorina species have become model organisms for the study of population biology, physiological adaptations, genetics, behavior, and parasitology (Johannesson et al., 1997; Sokolova et al. 2000, Sokolova and Pörtner 2001a,b; Panova and Johannesson, 2004; Panova et al., 2006; Quesada et al., 2007; Mikhailova et al., 2009; Conde-Padín et al. 2009, Granovitch et al. 2009; Galindo et al., 2010; Granovitch and Maximovich, 2013; Granovitch et al., 2013; Storey et al. 2013; Butlin et al., 2014; Lobov et al., 2015; Rolan-Alvarez et al., 2015; Maltseva et al., 2016; Westram et al., 2014; Ravinet et al., 2016, Granovitch, 2016). Along the North Atlantic shore, Littorina saxatilis (Olivi, 1872) and L.obtusata (Linnaeus, 1758) are most common (Reid, 1996). L. saxatilis is characterized by a wide geographic range, a considerable interspecies variability, and an ability to survive in brackish waters of estuaries (Berger, 1986; Reid, 1996; Granovitch et al., 2004). This species was chosen earlier for analysis of adaptation to acute osmotic stress (freshening down to $10 \%$ ) using proteomic methodology (Muraeva et al., 2016). The second species (L.obtusata) has been shown to be less tolerant to low salinity (Berger, 1986) but had not previously been studied on a proteomic level. In this study, we modeled a mild osmotic stress (a decrease of salinity from 24 to $14 \%$ ) to compare the response of proteomes (1) to salinity stress of different magnitude in one species and (2) to mild salinity stress in two related species. Our study demonstrated that the effect of mild stress was expectedly weaker in comparison to the effect of acute stress; and that changes in the proteomes of two closely related species differed under stress conditions.

\section{Material and methods}

Animals. Snails L. saxatilis and L.obtusata were collected from wild populations in the vicinity of the White Sea Biological Station "Kartesh" (the Chupa Inlet of the Kandalaksha Bay, the White Sea) on October 15-16, 2014. Salinity in this region varies within the range of $\sim 20-28 \%$ depending on the season and weather. The snails were transported to St. Petersburg in wet containers in a thermostatic chamber at $4{ }^{\circ} \mathrm{C}$. Before the experimental exposure, adult molluscs with shell height exceeding $7 \mathrm{~mm}$ were acclimated to the standard laboratory conditions $\left(24 \%, 4^{\circ} \mathrm{C}\right.$, aeration) for 7 days. Once a day, water was removed for 3-4 h from the containers where the snails were kept to imitate tides. No feeding was provided.

Low salinity stress. Two groups of six animals each ( 3 males and 3 females, healthy mature individuals without trematode infection) were fixed to obtain tissue lysate before the start of the experiment as an "intact" control ("zero-point"). The rest of the animals were separated into two groups and put into containers with seawater of salinity either $14 \%$ (mild salinity stress) or $24 \%$ (dynamic control). The seawater used in the experiment was drawn near the Kartesh Cape at $5 \mathrm{~m}$ depth; it was diluted with distilled water to salinity $14 \%$. Tide imitation was performed daily in both experimental groups. Throughout the experiment ( 6 days) we examined the presence/absence of the isolation reaction. On the second, fourth and sixth days of the experiment, the molluscs from both experimental groups were sampled in two replicates to obtain tissue lysates ( 3 male and 3 females in each sample).

Sample preparation. Tissue lysates were prepared and analyzed as described previously (Muraeva et al., 2016; Maltseva at al., 2016). Here we present only a short summary of the protocol. The soft body was withdrawn from the shell and put into a cold lytic buffer $(25 \mathrm{mM}$ tris $\mathrm{pH} 8.5,7 \mathrm{M}$ urea, $2 \mathrm{M}$ thiourea, $4 \% \mathrm{CHAPS})$. Several individuals ( 3 males and 3 females) were pooled in $1 \mathrm{ml}$ of the lytic buffer (to improve reliability of samples, Diz et al., 2009). Two replicates were made for every experimental time point. Tissues were homogenized in the lysis buffer using a Mixer Mill 400 (Retsch, Germany); particles were sedimented by centrifugation at $12000 \mathrm{~g}$ for $15 \mathrm{~min}$ at $4^{\circ} \mathrm{C}$, and supernatants were frozen at $-80^{\circ} \mathrm{C}$ until use.

2D DIGE. Samples were analyzed using 2-dimensional difference gel electrophoresis (Ünlü et al., 1997). Total protein concentration was determined following the Bradford method with a 96-well plate spectrophotometer Epoch 2 (Epoch Microplate Spectrophotometer, BioTek Instruments, USA). Proteins of the tissue lysates were conjugated with fluorescent dyes $\mathrm{Cy} 2, \mathrm{Cy} 3$ or Cy5 (LuminoProbe, BioDye, Russia) with 400 pmol of a 
fluorophore per $\sim 50 \mu \mathrm{g}$ of total protein, and then incubated for 30 min on ice in the dark. Dye swap was done when conjugating a corresponding sample of biological replicates. The reaction was stopped by adding $10 \mu \mathrm{mol}$ of L-lysine in a buffer ( $25 \mathrm{mM}$ tris, $\mathrm{pH}$ 8.5), followed by incubation for 10 min under the same conditions. Three samples for comparison were pooled then; dithiothreitol (Sigma-Aldrich, USA; up to concentration $100 \mathrm{mM}$ ) and biolytes (BioRad, USA; up to concentration $0.4 \%$ ) were added. The mixed samples were loaded into an IPG ReadyStrip (7 cm, pH 3-10, BioRad, USA) via passive rehydration (overnight at room temperature, in the dark). Separation in the first direction was carried out in a Protean IEF Cell (BioRad, USA) using the method recommended by the manufacturer: $10000 \mathrm{Vh}$, end voltage $4000 \mathrm{~V}$, rapid ramp, $20^{\circ} \mathrm{C}$. Before the separation in the second direction, IPG-strips with focused proteins were incubated in the equilibration buffers $(6 \mathrm{M}$ urea, $2 \%$ SDS, $20 \%$ glycerol, $0.375 \mathrm{M}$ tris, $\mathrm{pH} 8.8$ ) for $15 \mathrm{~min}$ : first with $2 \%$ dithiothreitol; and then with $2.5 \%$ iodoacetamide. Electrophoresis in the second direction was performed in a MiniProtean TetraCell (BioRad, USA) in $15 \%$ PAAG in tris/glycine/SDS buffer (BioRad, USA). A GE Typhoon 9500 FLA laser scanner (GE Healthcare, USA) was used for visualization.

Images processing. Qualitative and quantitative gel analysis was carried out using PDQuest Advanced 8.0.1 software (BioRad, USA). A spot was included into the analysis if it was detected in all groups of comparison (control "zero-point", $14 \%$ and $24 \%$ at $2^{\text {nd }}, 4^{\text {th }}$ and $5^{\text {th }}$ days) in at least one replicate or in at least one group in both replicates. A total of 267 significant spots were identified during analysis of L. saxatilis samples, and 281 spots were identified in the analysis of L.obtusata. Normalization for the spots intensities estimates was done on total gel density using PDQuest embedded algorithm. Merging of the electrophoregrams was performed using ImageJ $1.48 \mathrm{v}$ (Wayne Rasband, National Institutes of Health, USA, http://imagej.nih.gov.ij).

Protein identification. Mass-spectrometry identification of proteins was carried out in accordance with a "bottom up" methodology - via MS/MS-analysis of tryptic peptides with a database search. For trypsinization, spots of interest were excised from the Coomassie Brilliant Blue G250 stained gel. Gel pieces were destained with $50 \%$ acetonitrile/ $25 \mathrm{mM}$ tris, $\mathrm{pH}$ 8.2, dehydrated in $100 \%$ acetonitrile and rehydrated in bovine trypsin solution (20 ng/ $\mu \mathrm{L} / 25 \mathrm{mM}$ tris, $\mathrm{pH} 8.2$ ) on ice for $60 \mathrm{~min}$. After rehydration, any excessive trypsin solution was removed, and the gel pieces were covered with $25 \mathrm{mM}$ tris, $\mathrm{pH} 8.2$ and incubated at $37^{\circ} \mathrm{C}$ overnight. Tryptic peptides were eluted with $50 \%$ acetonitrile, $0.1 \%$ formic acid, and were vacuum dried to $10 \mu \mathrm{l}$ volume. Samples were analyzed using LC (Agilent 1260)-MS/MS (QTOF UHD 5238, Agilent Technologies, USA). The elution method was $10 \% \mathrm{~B}$ to $60 \% \mathrm{~B}$ for $25 \mathrm{~min}$ and further to $100 \%$ B for $5 \mathrm{~min}$, where B was $90 \%$ acetonitrile $/ 0.1 \%$ formic acid; A was $5 \%$ acetonitrile $/ 0.1 \%$ formic acid; flow rate $15 \mu \mathrm{L} / \mathrm{min}$; and column Zorbax SB-C18 (Agilent Technologies, USA), $5 \mu \mathrm{m}$ grain, $80 \mathrm{~A}$ pores, $150 \times 0.5 \mathrm{~mm}$. Mass analysis was carried out with constant reference signal; detection frequency 3 spectra/ sec, automatic MS/MS, mother ions $2+, 3+, \mathrm{n}+$. An MS/ MS search was carried out in the mode "Identity" using Agilent Technologies Spectrum Mill software. For protein identification, we used the L. saxatilis EST database http://mbio-serv2.mbioekol.lu.se/Littorina1/ (Canbäck et al., 2012).

Statistical analysis. All analyses were performed in R (R Core Team, 2017). Missing spot intensities were imputed using Bayesian principal component analysis (Bishop, 1999) in pcaMethods package (Stacklies et al., 2007). Afterwards, the data were normalized using quantile normalization, $\log 2$-transformed, and the technical replicates were averaged.

To visualize the overall similarity of proteomes, we performed nonmetric multidimensional scaling (nMDS) on a matrix of Bray-Curtis dissimilarities among samples in vegan package (Oksanen et al., 2017).

To construct expression profiles of individual proteins, we averaged biological replicates and standardized expression values by treatment and exposure group. The protein expression profiles were clustered based on matrix of Euclidean distances with unweighted pair-group average method (UPGMA). Bootstrap support values were obtained using multiscale bootstrap with 1000 iterations in package pvclust (Suzuki and Shimodaira, 2015). The dendrograms were plotted with the help of dendextend package (Galili, 2015). The trees of protein profiles were divided into significant clusters based on bootstrap support values. The proteins that grouped together with high support (AU p-value >95) were considered a significant cluster. For L.obtusata the whole process was automated using the function pvpick from pvclust package. For L. saxatilis, the largest of the two significant clusters was additionally manually subdivided into smaller significant subclusters. The proteins which grouped with low support, but within a significant subcluster, were included into that cluster. The proteins which did not form significant clusters were grouped into an artificial subcluster. The expression profiles for each cluster were plotted with the help of ggplot2 package (Wickham, 2009) and visually screened for asymmetry. The proteins from the most asymmetric clusters, in which expression dynamics differed at $14 \%$ and $24 \%$, were considered as potentially regulated under mild salinity stress. 


\section{Results}

1. Mild osmotic stress does not affect snail survival and motility. The behavior and vitality of the molluscs were checked throughout the experiment in both incubated groups ( $14 \%$ and $24 \%$ ) of both species (L. saxatilis and L.obtusata) with no differences detected. There was no mortality; snails did not isolate either under or without the water and demonstrated usual locomotor and feeding (scratching by radula) activity.

\section{Laboratory maintenance under normal condi-} tions causes physiological changes. Multidimensional scaling, which was used for visualization of similarity between proteomes, showed that distances were greater among different time points than between different salinities within the same time point (Fig. 2 and 3). This was true for both species, and it implies that laboratory maintenance without feeding during acclimation and exposure periods affects proteomes stronger than mild osmotic stress (a change of salinity from 24 to $14 \%$ ).

3. Salinity drop affects expression of several functional groups of proteins. To reveal the proteins which changed abundance with a drop in salinity, we assembled "hybrid" expression profiles, reflecting abundance dynamics during both $14 \%$ and $24 \%$ for each protein (Fig. 1). These expression profiles were clustered to distinguish characteristic patterns of expression change (Supplement 1 and 2). Among the clusters of expression profiles (Supplement 3 and 4), we have selected the proteins with the most asymmetric temporal patterns of expression at $14 \%$ and $24 \%$ relative to the initial state (Fig. 4 and 5). In total, 28 proteins of L. saxatilis $(\sim 10 \%)$ and 18 proteins of L.obtusata $(\sim 6 \%)$ were recognized as regulated during mild salinity stress. Among these proteins there were members of several functional groups (Table 1): antioxidant proteins (glutathione-Stransferase), chaperons (small heat shock protein), ion channels (Vdac-2), metabolic enzymes (arginine-kinase; ATP-synthase), cytoskeleton proteins (light chain of myosin, alpha-tubulin, troponin T), extracellular matrix proteins (matrilin) and regulatory proteins (tyrosine 3-monooxygenase, translationally-controlled tumor protein). The full list of the significant clusters' content and master-gels of analyzed proteomes are presented in Supplement 5.

4. Stress response in two related species differs. The proteomic response was slightly stronger in L. saxatilis compared to L.obtusata (see above): the abundance of approximately $10 \%$ and $6 \%$ of detected proteins experienced regulation, respectively. Nevertheless, only two of those proteins were common for the two species (small heat shock protein and translationally-controlled tumor protein). Other differentially expressed proteins did not match between two species as can be concluded from their positions on the gel (the majority of them were

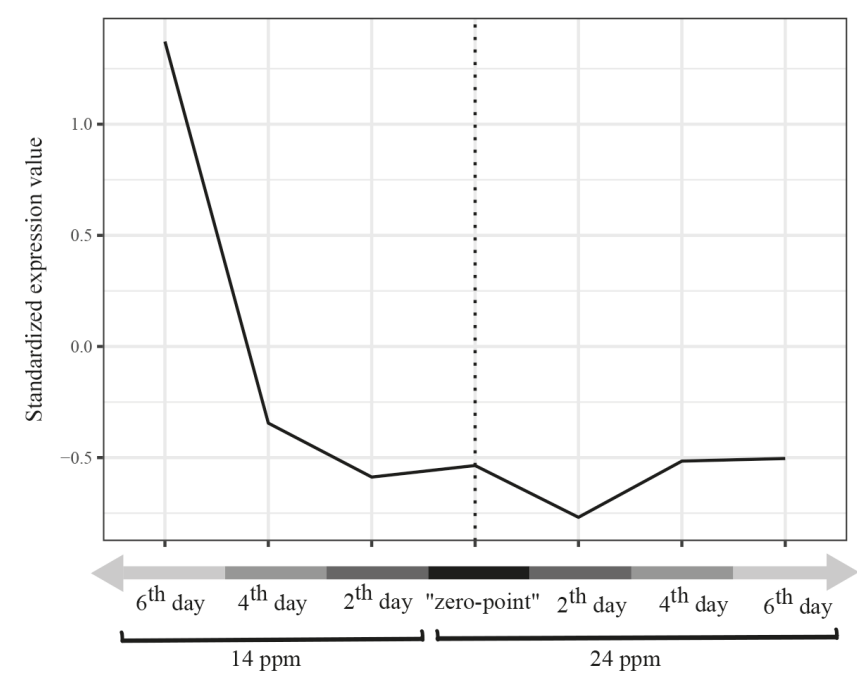

Fig. 1. An example of a protein expression profile, which reflects dynamics of abundance during both $14 \%$ and $24 \%$ starting at "zero-point", corresponding to intact animals at the start of experiment. This particular profile belongs to L. saxatilis gel-spot 2605, corresponding to Vdac-2.

not identified), but some of them represented the same functional groups (e.g., tubulin in L. obtusata vs myosin and troponin in L. saxatilis are all cytoskeletal proteins).

\section{Discussion}

The response to low salinity. In this study, we exposed the intertidal snails of two species to mild osmotic stress (salinity change from 24 to $14 \%$ ) under laboratory conditions and evaluated changes in proteomes using a 2D gel-based approach, followed by MS-based proteins identification. There were no effects on behavior or survival of experimental animals, unlike in the previously studied acute stress in L. saxatilis, with salinity drop to $10 \%$ (Muraeva et al., 2016). This indicates that salinity of $14 \%$ falls within the tolerance range of both species, while $10 \%$ is already a part of the resistance range of L. saxatilis and apparently of L.obtusata, which is less tolerant to low salinity (Berger, 1986).

The general scale of proteomic changes in L. saxatilis was expectedly weaker under mild stress conditions compared to acute ones: although in both cases $\sim 10 \%$ of proteins were found regulated, the sensitivity of the methodology was higher in the analysis of the "mild" experiment results. Another mark of relative weakness of response to mild stress was the fact that the strength of salinity-related changes was similar to the strength of changes related to laboratory maintenance. In contrast, this was not the case in the acute experiment, partially due to continuous isolation reaction (up to $4^{\text {th }}$ day inclusively): consequent hypoxia and acidosis prominently affect organisms in addition to low salinity influence per se. The composition of differentially expressed proteins under two types of stress partially overlapped. Thus, in 


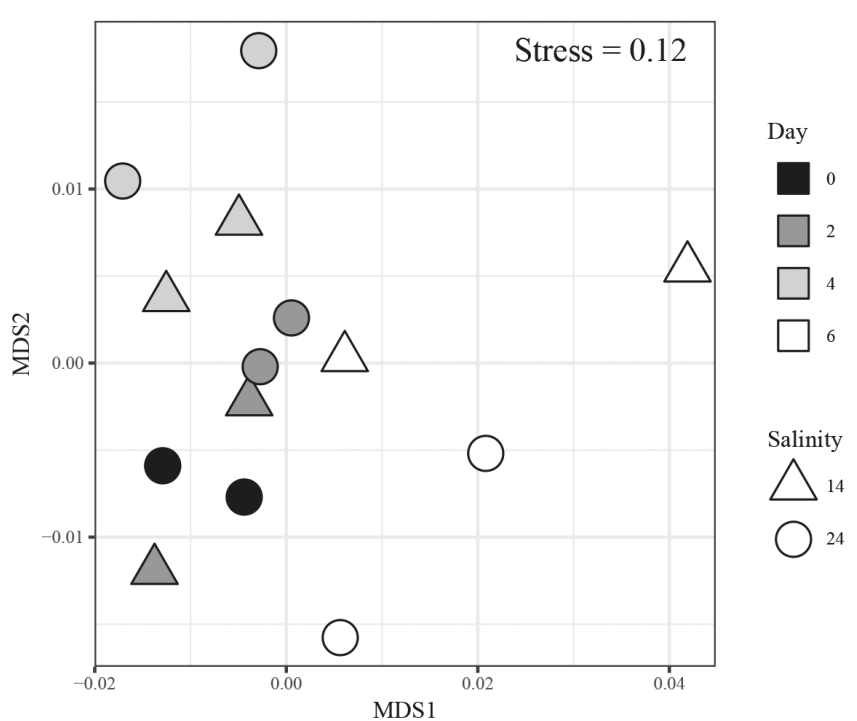

Fig. 2. Nonmetric multidimensional scaling of L. saxatilis proteomes. Exposure duration is indicated by different hues of gray; triangles correspond to low salinity $(14 \%)$ ) and circles to control $(24 \%)$.

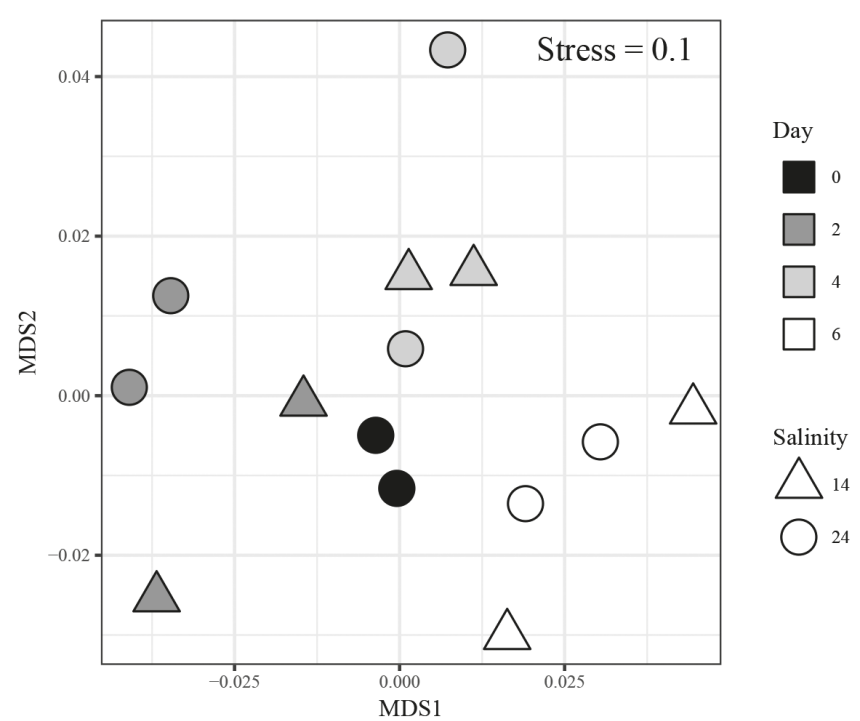

Fig. 3. Nonmetric multidimensional scaling of L. obtusata proteomes. Exposure duration is indicated by different hues of gray; triangles correspond to low salinity $(14 \%)$ and circles to control (24\%).

Table 1. Identified differentially expressed proteins. LSD: L. saxatilis database; MW: molecular weight of a protein in accordance to database. $\mathrm{MH}+$ : molecular weight of a single positively charged ion of an identified peptide

\begin{tabular}{|c|c|c|c|c|c|c|}
\hline $\begin{array}{c}\text { Spot } \\
\mathrm{N}\end{array}$ & \begin{tabular}{|c|} 
Cluster \\
$\mathbf{N}$
\end{tabular} & \begin{tabular}{|l|} 
Type of \\
regulation
\end{tabular} & Protein, accesion number (database), peptide sequences & $\mathrm{MH}+, \mathrm{Da}$ & \begin{tabular}{|c|} 
Theoretical \\
MW (kDa)
\end{tabular} & Species \\
\hline X2605 & 0 & up & $\begin{array}{l}\text { Vdac2 protein, c819 (LSD) } \\
\text { (K)GYNYGFFK(L) } \\
\text { (K)LAFDTSFAPQTGK(K) } \\
\text { (K)LAFDTSFAPQTGKK(S) } \\
\text { (K)LTLSALIEGK(S) } \\
\text { (K)VNNSSQIGLGSQK(L) } \\
\text { (R)VNPDLETAVNLSWTSGTNATR(F) } \\
\text { (K)WSEYGLNFTEK(W) }\end{array}$ & $\begin{array}{l}995.4621 \\
1382.6951 \\
1510.7900 \\
1044.6299 \\
1494.7547 \\
2246.1048 \\
1373.6371\end{array}$ & $30.3 \mathrm{kDa}$ & L. saxatilis \\
\hline X2702 & 0 & down & $\begin{array}{l}\text { Arginin kinase, c5132 (LSD) } \\
\text { (K)LAATPEFK(E) } \\
\text { (R)ASVHIKIPK(L) } \\
\text { (R)LVSAIETMEK(K) } \\
\text { (R)LGLSEFDAIMENK(N) }\end{array}$ & $\begin{array}{l}876.4825 \\
992.6251 \\
1120.5918 \\
1483.7171\end{array}$ & $39.3 \mathrm{kDa}$ & L. saxatilis \\
\hline X7506 & 0 & down & $\begin{array}{l}\text { Tyrosine 3-monooxygenase/tryptophan 5-monooxygenase } \\
\text { activation protein, epsilon polypeptide, c9110 (LSD) } \\
\text { (K)AAFDDAIAELDTLSEESYK(D) } \\
\text { (K)AAFDDAIAELDTLSEESYKDSTLIMQLLR(D) }\end{array}$ & $\begin{array}{l}2087.9655 \\
3258.6086\end{array}$ & $29.2 \mathrm{kDa}$ & L. saxatilis \\
\hline X8002 & 4 & up & $\begin{array}{l}\text { Ribosomal protein, c16990 (LSD) } \\
\text { (K)ILSSVGIEAEADKVK(K) }\end{array}$ & 1558.8687 & $11.5 \mathrm{kDa}$ & L. saxatilis \\
\hline X9903 & 4 & up & $\begin{array}{l}\text { Matrilin, c1810 (LSD) } \\
\text { (K)DLVDTLAGIDWR(H) } \\
\text { (R)VVIVLTDGNSQETALTK(X) }\end{array}$ & $\begin{array}{l}1373.7060 \\
1787.9749\end{array}$ & $45.5 \mathrm{kDa}$ & L. saxatilis \\
\hline X7502 & 6 & down & unknown & & & L. saxatilis \\
\hline X8205 & 6 & down & $\begin{array}{l}\text { Myosin regulatory light chain, c1759 (LSD) } \\
\text { (K)GKFNYNEFVSILK(G) } \\
\text { (K)GKFNYNEFVSILKGKQEDEGQPA(-) } \\
\text { (R)ATSNVFAMFR(Q) }\end{array}$ & $\begin{array}{l}1558.8264 \\
2598.2835 \\
1143.5615\end{array}$ & $13.9 \mathrm{kDa}$ & L. saxatilis \\
\hline X4902 & 7 & up & unknown & & & L. saxatilis \\
\hline X6901 & 7 & up & unknown & & & L. saxatilis \\
\hline X3901 & 15 & up & $\begin{array}{l}\text { ATP synthase subunit alpha, c131 (LSD) } \\
\text { (K)APGIIPR(T) } \\
\text { (K)AVDSLVPIGR(G) } \\
\text { (R)STVAQLVK(R) } \\
\text { (R)TSVKEPMQTGIK(A) } \\
\text { ATP synthase subunit alpha, c2055 (LSD) } \\
\text { (R)TGAIVDVPVGR(E) } \\
\text { (R)VVDALGNPIDGKGPLGSSER(L) }\end{array}$ & $\begin{array}{l}723.4512 \\
1026.5942 \\
845.5091 \\
1318.7035 \\
\\
1081.6157 \\
1981.0349\end{array}$ & $59.7 \mathrm{kDa}$ & L. saxatilis \\
\hline
\end{tabular}




\begin{tabular}{|c|c|c|c|c|c|c|}
\hline$\times 6005$ & 15 & up & unknown & & & L. saxatilis \\
\hline X3203 & 19 & down & unknown & & & L. saxatilis \\
\hline X6402 & 19 & down & unknown & & & L. saxatilis \\
\hline X6603 & 19 & down & $\begin{array}{l}\text { Tyrosine-3-monooxygenase, c2612 } \\
\text { (K)LAEQAERYDDMAEAMR(N) } \\
\text { (R)NLLSVAYK(N) }\end{array}$ & $\begin{array}{l}1898.8371 \\
907.5247\end{array}$ & $29.2 \mathrm{kDa}$ & L. saxatilis \\
\hline X1502 & 20 & up & $\begin{array}{l}\text { Sigma class glutathione-s-transferase 3, c1445 (LSD) } \\
\text { (R)LLLHATGQPFEDVR(V) } \\
\text { (K)YGQSLAIGPFLAR(K) }\end{array}$ & $\begin{array}{l}1595.8540 \\
1392.7634\end{array}$ & $23.0 \mathrm{kDa}$ & L. saxatilis \\
\hline X2401 & 20 & up & $\begin{array}{l}\text { Small heat shock protein, c4901 (LSD) } \\
\text { (R)VNVDVQQFKPEEINVK(T) }\end{array}$ & 1886.0018 & $18.9 \mathrm{kDa}$ & L. saxatilis \\
\hline X9004 & 20 & up & unknown & & & L. saxatilis \\
\hline X3503 & 24 & down & unknown & & & L. saxatilis \\
\hline X1402 & 24 & down & unknown & & & L. saxatilis \\
\hline X3201 & 24 & down & unknown & & & L. saxatilis \\
\hline X3202 & 24 & down & unknown & & & L. saxatilis \\
\hline X3502 & 24 & down & unknown & & & L. saxatilis \\
\hline X7302 & 24 & down & $\begin{array}{l}\text { Translationally-controlled tumor protein, c287 (LSD) } \\
\text { (K)DLSFYGAEPR(E) } \\
\text { (K)FTVAWAPK(A) }\end{array}$ & $\begin{array}{l}1154.5477 \\
919.5036\end{array}$ & & L. saxatilis \\
\hline X9502 & 29 & up & unknown & & & L. saxatilis \\
\hline X3704 & 29 & up & $\begin{array}{l}\text { Troponin T, c420 (LSD) } \\
\text { (K)GATVMVDESFDR(L) } \\
\text { (R)LVGDKYDLEQR(F) } \\
\text { (R)QQYDMIELAER(A) } \\
\text { (R)RLVGDKYDLEQR(F) } \\
\text { (R)TYVER(K) }\end{array}$ & \begin{tabular}{|l|}
1326.5994 \\
1335.6903 \\
1395.6573 \\
1491.7914 \\
667.3410
\end{tabular} & $38.0 \mathrm{kDa}$ & L. saxatilis \\
\hline X9401 & 29 & up & unknown & & & L. saxatilis \\
\hline $\mathrm{X} 1505$ & 33 & up & unknown & & & L. saxatilis \\
\hline X5702 & 33 & up & $\begin{array}{l}\text { Troponin T, c420 (LSD) } \\
\text { (K)GATVMVDESFDR(L) } \\
\text { (K)KGATVMVDESFDR(L) } \\
\text { (R)LVGDKYDLEQR(F) } \\
\text { (R)QQYDMIELAER(A) } \\
\text { (R)RLVGDKYDLEQR(F) }\end{array}$ & \begin{tabular}{|l|}
1326.5994 \\
1454.6944 \\
1335.6903 \\
1395.6573 \\
1491.7914
\end{tabular} & $38.0 \mathrm{kDa}$ & L. saxatilis \\
\hline X5706 & 11 & up & $\begin{array}{l}\text { Tubulin alpha1, c2217 (LSD) } \\
\text { (R)AVFVDLEPTVIDEVR(T) } \\
\text { (K)DVNAAIATIK(T) } \\
\text { (K)EIVDLVLDR(I) } \\
\text { Tubulin alpha1, c1018 (LSD) } \\
\text { (R)AVFVDLEPTVIDEVR(T) } \\
\text { (K)EIVDLVLDR(I) }\end{array}$ & $\begin{array}{l}1701.9058 \\
1015.5782 \\
1071.6045 \\
\\
1701.9058 \\
1071.6045\end{array}$ & $39.3 \mathrm{kDa}$ & L. obtusata \\
\hline X7905 & 11 & up & unknown & & & L. obtusata \\
\hline X8308 & 24 & down & unknown & & & L. obtusata \\
\hline X4404 & 24 & down & unknown & & & L. obtusata \\
\hline X6906 & 24 & down & unknown & & & L. obtusata \\
\hline X7608 & 40 & down & unknown & & & L. obtusata \\
\hline$X 7230$ & 40 & down & $\begin{array}{l}\text { Unknown protein Crassostrea/Aplysia, c8291 (LSD) } \\
\text { (K)VVLPTGEDVQQEK(T) }\end{array}$ & 1441.7533 & & L. obtusata \\
\hline X7607 & 40 & down & unknown & & & L. obtusata \\
\hline X8411 & 44 & down & $\begin{array}{l}\text { Translationally-controlled tumor protein, c287 (LSD) } \\
\text { (K)FTVAWAPK(A) }\end{array}$ & 919.5036 & & L. obtusata \\
\hline X3815 & 44 & down & unknown & & & L. obtusata \\
\hline X5609 & 44 & down & unknown & & & L. obtusata \\
\hline X5409 & 48 & up & unknown & & & L. obtusata \\
\hline X8605 & 48 & up & unknown & & & L. obtusata \\
\hline X1204 & 48 & up & $\begin{array}{l}\text { Small heat shock protein, c4901 (LSD) } \\
\text { (R)VNVDVQQFKPEEINVK(T) }\end{array}$ & 1886.0018 & $18.9 \mathrm{kDa}$ & L. obtusata \\
\hline X1904 & 48 & up & unknown & & & L. obtusata \\
\hline X1905 & 48 & up & unknown & & & L. obtusata \\
\hline X1912 & 48 & up & unknown & & & L. obtusata \\
\hline X4410 & 48 & up & unknown & & & L. obtusata \\
\hline
\end{tabular}




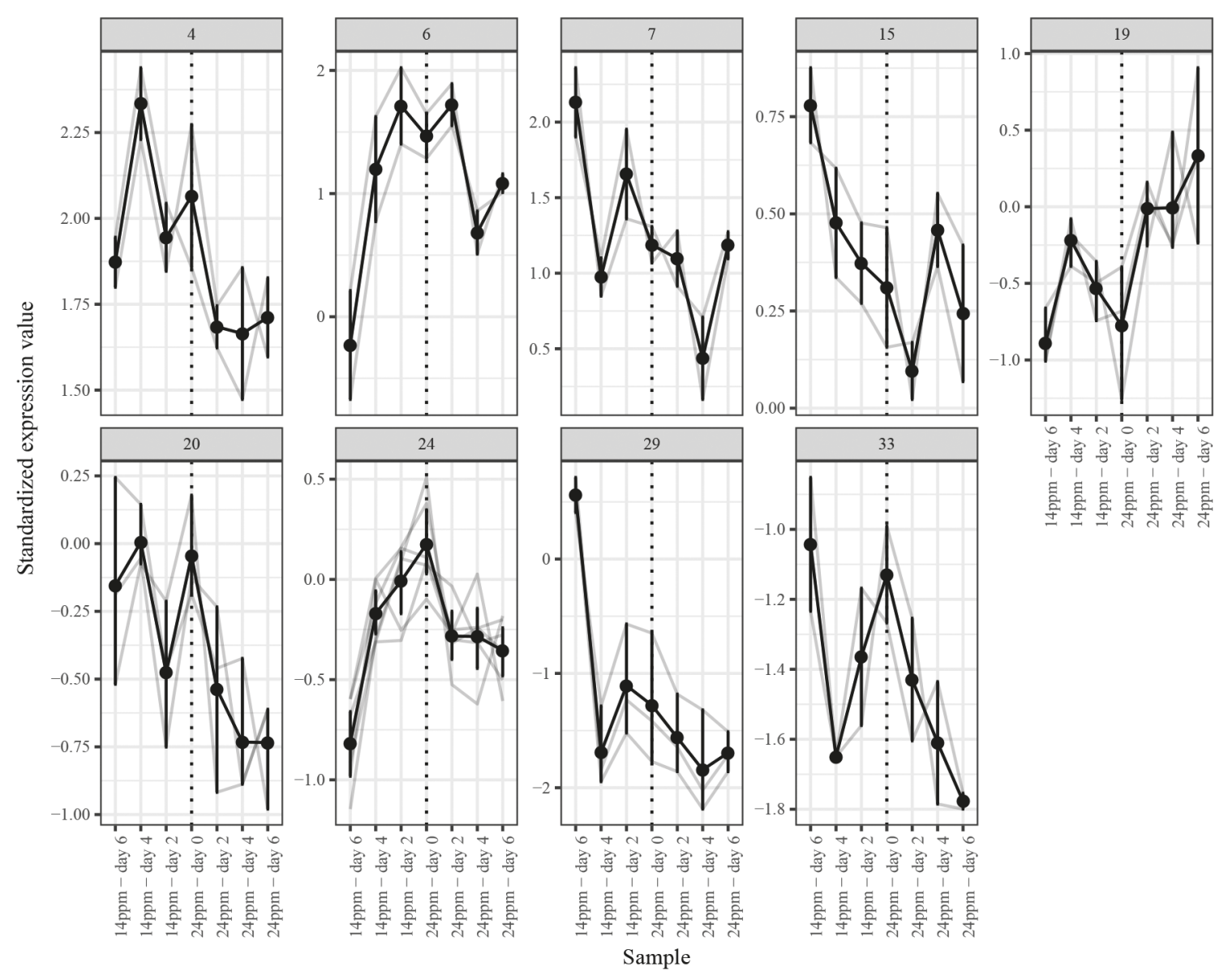

Fig. 4. Clusters of proteins of L. saxatilis with asymmetric temporal patterns of expression at $14 \%$ and $24 \%$ during the experiment relative to the initial state.
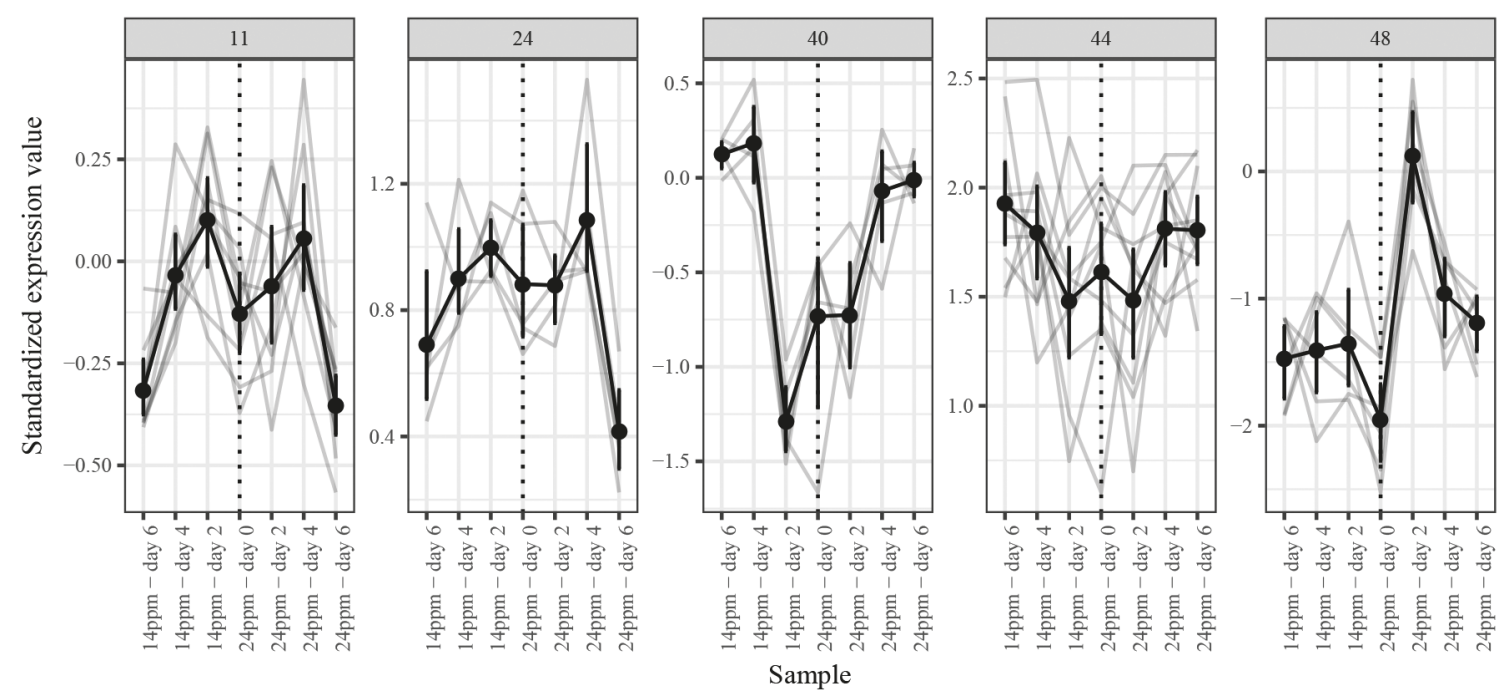

Fig. 5. Clusters of proteins of L. obtusata with asymmetric temporal patterns of expression at $14 \%$ and $24 \%$ during the experiment relative to the initial state.

both cases, forms of small heat shock protein, argininekinase, ATP-synthase (even different subunits), matrilin, tyrosine-3-monooxygenase/tryptophan 5-monooxygenase activation protein were shown to undergo abundance regulation. Glutathione-S-transferase was detected as regulated during mild stress, while thioredoxin-peroxidase differentially expressed during acute stress, both being antioxidant proteins (Muraeva et al., 2016).

The proteomic changes in L.obtusata were slightly weaker than in L.saxatilis. Only three proteins (small 
heat shock protein, unknown protein Crassostrea/Aplysia and translationally-controlled tumor protein) were identified among 18 proteins with low-salinity-related abundance changes; two of them were also detected in L. saxatilis. Unidentified regulated proteins do not correspond to those of L. saxatilis, though they could belong to the same functional groups, like identified cytoskeletal proteins. Thus, although the scale of response of these species was roughly comparable, the sets of executive proteins matched only partially, which may be related to differences in their tolerant ranges (Berger, 1986).

Differentially expressed proteins. Arginine-kinase (AK) is a functional analogue of vertebrates' creatinekinase. These enzymes are responsible for an alternative pathway of ATP synthesis: they catalyze the transfer of phosphate from phosphoarginine to ADP under conditions of insufficient oxidative phosphorylation within mitochondria (Morrison, 1973). Thus, phosphoarginine is actively consumed by tissues under oxygen deficiency conditions. The up-regulation of AK in the acute salinity stress experiment was most likely related to isolationcaused hypoxia. Similarly, compensatory upregulation of AK during thermal/hypoxic stress was shown in other invertebrates: blue mussels (Tomanek and $\mathrm{Zu}$ zow, 2010), snails Echinolittorina (Wang, 2013), shrimps Fenneropenaeus (Jiang et al., 2009) and Marsupenaeus japonicas (Abe et al., 2007). Under mild stress conditions, there was no isolation-related hypoxia, and AK was temporally down-regulated. Down-regulation of proteins not urgently needed during stress has been detected previously, and may demonstrate a kind of cellular economy reaction (Warner, 1999; Weber et al., 2006; Muraeva et al., 2016). Interestingly, the abundance of another enzyme of energetic metabolism, ATP-synthase, which is involved in the oxidative phosphorylation process, increased in both experiments. During mild stress response, the up-regulation was quite fast, while during acute stress it was delayed until the $5^{\text {th }}$ day, when snails began to open their shells during tide-imitation after continuous isolation (Muraeva et al., 2016). This implies that the metabolic intensification may be involved in any type of salinity stress response, but it was delayed under acute stress conditions due to long isolation reaction.

Vdac-2 is a voltage-dependent anion channel, a very conservative member of the porin-family, located in the outer membrane of mitochondria. It plays an important role in regulation of metabolic and energeticrelated transport between cytosol and mitochondrion (Lemasters et al., 2006). This protein is also known to be a regulator of apoptosis (Tsujimoto and Shimizu, 2002). In agreement with this, Vdac-2 inhibited apoptosis in oysters Crassostrea gigas during viral infection (Li et al., 2016). The regulation of this protein was also established during thermal stress in bivalve Geukensia demissa (Fields et al., 2016) and during osmotic stress in plants (Kumari et al., 2009; Wen et al., 2011). Thus, Vdac-2 protein can be involved in cell protection under different stress conditions in different organisms.

A translationally-controlled tumor protein (TCTP) is another putative regulator of apoptosis with detected changes in abundance within cells. This house-keeping protein interacts with several cytosolic targets, e.g., tubulin, TSAP6, etc., and is involved in regulation of cell cycle, growth and proliferation (Bommer and Thiele, 2004; Tuynder et al., 2004). TCTP is also an important participant of the TOR-pathway, a nutrition sensor and growth regulator in different organisms (Deprost et al., 2007; Brioudes et al., 2010). Its regulation was detected during salinity stress in plants and bacteria (Vincent et al., 2007; Santa Brígida et al., 2014). TCTP proved to be down-regulated during mild salinity stress in both Littorina species. This may be interpreted as a sign of repartition of energy between stress reaction and growth processes in organism.

Chaperones are responsible for renaturation of damaged proteins and folding of de novo synthesized ones, and the prevention of apoptosis by these proteins also was reported (Hartl, 1996; Kamradt et al., 2005; Hartl et al., 1996). The participation of heat shock proteins in salinity adaptation has been demonstrated many times in different taxa: protists Amoeba proteus and Paramecium jenningsi (Plekhanov et al., 2006); sponges Tetilla mutabilis (Kültz et al., 2007); corals Seriatopora caliendrum (Seveso et al., 2013); sea cucumbers Apostichopus japonicas (Meng et al., 2011); oysters Crassostrea gigas (Zhao et al., 2012); and mussels Mytilus galloprovincialis, M. trossulus (Tomanek et al., 2012) and M. edulis (Podlipaeva et al., 2012, 2016). In our study, heat shock proteins were the only protein group which we revealed as important for low salinity adaptation in both stress types and in both species studied.

Different types of stress (thermal, osmotic or hypoxic) are accompanied by an appearance of toxic reactive forms of oxygen, damaging cellular structures (Lushchak, 2011). Glutathione-S-transferase (GST) belongs to the diverse group of cytosolic and mitochondrial enzymes which defend the cell against various harmful agents produced endogenously or acquired from the environment. GST catalyzes conjugation of reduced glutathione with electrophilic targets, both environmental toxicants or numerous by-products of oxidative stress causing their inactivation (Hayes and Strange, 2000; Strange et al, 2001). The importance of GST for cell defense during osmotic stress has been demonstrated in several marine invertebrates, e.g., in bivalve species of the Veneridae family (Carregosa et al., 2014). Other antioxidant proteins also were involved in overcoming salinity and hypoxic stress: superoxide-anion dismutase and catalase in holothuria Apostichopus japonicus (Wang et al., 2008); catalase, thioredoxin peroxidase and glutathione peroxidase in snails 
Haliotis discus discus (De Zoysa et al., 2010); a diverse set of antioxidant enzymes in mussels M.galloprovincialis and M.trossulus (Lockwood and Somero, 2011). We detected up-regulation of GST in L. saxatilis in this study, while thioredoxin peroxidase was regulated in the same species during acute salinity stress (Muraeva et al., 2016). Thus, activation of the antioxidant system is an essential part of adaptation to low salinity in this species as well as in other organisms.

Tyrosine-3-monooxygenase (Tyr-3-m) is the first enzyme in a pathway of catecholamine synthesis from tyrosine. Catecholamines (e.g., adrenaline and noradrenaline) are hormones and neurotransmitters with many effects on different cellular and organismal functions; in particular, those mediators participate in regulation of the stress response. Up-regulation of Tyr-3-m was described as a part of thermal stress response in corals Scleronephthya gracillimum (Woo et al., 2006). Unexpectedly, in this study we detected down-regulation of this enzyme and its activator, which agrees well with previous results (down regulation of Tyr-3-m/tryptophan 5-monooxygenase activation protein) in the same species under acute salinity stress (Muraeva et al., 2016). The biological meanings of this down-regulation remain to be elucidated.

The detected increase of the relative abundances of matrilin (extracellular matrix protein) corroborates our previous results. Together with revealed regulation of several cytoskeletal proteins, controlling cell-shape, it implies the possible tissue remodeling under salinity stress, also inferred earlier. Up- and down-regulation of genes, coding for proteins of cytoskeleton, cell adhesion and extracellular matrix, was also shown to be part of the response to salinity stress in oysters C.gigas and other marine invertebrates (Tomanek et al., 2012; Zhao et al., 2012).

\section{Conclusions}

Increasing the stressful salinity value from $10 \%$ to $14 \%$ o drastically alters the response of intertidal molluscs L. saxatilis due to transition from resistance to tolerance range of this species. The response to mild water freshening $(14 \% 0)$ in this species was expectedly weaker (compared to $10 \%$ ) in terms of survival, behavior and characteristics of the proteome. The general scale of stress response of the related species L. obtusata was a bit weaker than that of L. saxatilis and was mainly fulfilled via other proteins (possibly belonging to the same functional groups). This difference might represent a background for the differences in salinity tolerance ranges between the two species studied. The main functional groups of proteins involved in an organism's response to low salinity in the studied species are antioxidant proteins, chaperones, metabolic enzymes and regulators, ion channels and cytoskeletal and extracellular matrix proteins. This fits well with data obtained in other organisms.

\section{Acknowledgements}

The study was performed with technical support from the Resource Center "Molecular and Cellular Technologies" of St. Petersburg State University, Educational and Scientific Marine Station of SPbSU.

\section{References}

Abe, H., Hirai, S., Okada, S. 2007. Metabolic responses and arginine kinase expression under hypoxic stress of the kuruma prawn Marsupenaeus japonicus. Comparative Biochemistry and Physiology Part A: Molecular \& Integrative Physiology 146(1):40-46. https://doi.org/10.1016/j.cbpa.2006.08.027

An, M. I., Choi, C. Y. 2010. Activity of antioxidant enzymes and physiological responses in ark shell, Scapharca broughtonii, exposed to thermal and osmotic stress: effects on hemolymph and biochemical parameters. Comparative Biochemistry and Physiology Part B: Biochemistry and Molecular Biology 155(1):34-42. https://doi.org/10.1016/j. cbpb.2009.09.008

Berger, V. Ya. 1986. Adaptatsiya morskikh mollyuskov k izmeneniyam solenosti sredy [Adaptations of Marine Mollusks to Changes of Environmental Salinity], Izdatelstvo Nauka, Leningrad.

Bishop, C. M., 1999. Bayesian pca. In: Advances in neural information processing systems: 382-388.

Bommer, U.A., Thiele, B.J. 2004. The translationally controlled tumour protein (TCTP). The International Journal of Biochemistry and Cell Biology 36(3):379-385. https:// doi.org/10.1016/S1357-2725(03)00213-9

Brioudes, F., Thierry, A. M., Chambrier, P., Mollereau, B., Bendahmane, M. 2010. Translationally controlled tumor protein is a conserved mitotic growth integrator in animals and plants. Proceedings of the National Academy of Sciences 107(37):16384-16389. https://doi.org/10.1073/ pnas.1007926107

Bussell, J. A., Gidman, E. A., Causton, D. R., Gwynn-Jones, D., Malham, S. K., Jones, M. L. M., ... Seed, R. 2008. Changes in the immune response and metabolic fingerprint of the mussel, Mytilus edulis (Linnaeus) in response to lowered salinity and physical stress. Journal of Experimental Marine Biology and Ecology 358(1):78-85. https://doi. org/10.1016/j.jembe.2008.01.018

Butlin, R. K., Saura, M., Charrier, G., Jackson, B., André, C., Caballero, A., ... Kemppainen, P. 2014. Parallel evolution of local adaptation and reproductive isolation in the face of gene flow. Evolution 68(4):935-949. https://doi. org/10.1111/evo.12329

Canbäck, B., André, C., Galindo, J., Johannesson, K., Johansson, T., Panova, M., ... Butlin, R. 2012. The Littorina sequence database (LSD) - an online resource for genomic data. Molecular ecology resources 12(1):142-148. https://doi.org/10.1111/j.1755-0998.2011.03042.x

Carregosa, V., Velez, C., Soares, A. M., Figueira, E., Freitas, R. 2014. Physiological and biochemical responses of three Veneridae clams exposed to salinity changes. Comparative Biochemistry and Physiology Part B: Biochemistry and Molecular Biology 177:1-9. https://doi.org/10.1016/j. cbpb.2014.08.001

Cheng, W., Juang, F. M., Chen, J. C. 2004. The immune response of Taiwan abalone Haliotis diversicolor supertexta and its susceptibility to Vibrio parahaemolyticus at different sa- 
linity levels. Fish and Shellfish Immunology 16(3):295-306. https://doi.org/10.1016/S1050-4648(03)00111-6

Conde-Padín, P., Caballero, A., Rolán-Alvarez, E. 2009. Relative role of genetic determination and plastic response during ontogeny for shell-shape traits subjected to diversifying selection. Evolution 63(5):1356-1363. https:// doi.org/10.1111/j.1558-5646.2009.00636.x

De Zoysa, M., Whang, I., Lee, Y., Lee, S., Lee, J. S., Lee, J. 2009. Transcriptional analysis of antioxidant and immune defense genes in disk abalone (Haliotis discus discus) during thermal, low-salinity and hypoxic stress. Comparative Biochemistry and Physiology Part B: Biochemistry and Molecular Biology 154(4):387-395. https://doi.org/10.1016/j. cbpb.2009.08.002

Deprost, D., Yao, L., Sormani, R., Moreau, M., Leterreux, G., Nicolaï, M., ... Meyer, C. 2007. The Arabidopsis TOR kinase links plant growth, yield, stress resistance and mRNA translation. EMBO Reports 8(9):864-870. https:// doi.org/10.1038/sj.embor.7401043

Diz, A.P., Truebano, M., Skibinski, D. O. 2009. The consequences of sample pooling in proteomics: an empirical study. Electrophoresis 30(17):2967-2975. https://doi. org/10.1002/elps.200900210

Fields, P. A., Burmester, E. M., Cox, K. M., Karch, K. R. 2016. Rapid proteomic responses to a near-lethal heat stress in the salt marsh mussel Geukensia demissa. Journal of Experimental Biology 219(17):2673-2686. https://doi. org/10.1242/jeb.141176

Galili, T.2015. dendextend: an R package for visualizing, adjusting and comparing trees of hierarchical clustering. Bioinformatics 31(22):3718-3720. https://doi. org/10.1093/bioinformatics/btv428

Galindo, J., Grahame, J. W., Butlin, R. K. 2010. An EST-based genome scan using 454 sequencing in the marine snail Littorina saxatilis. Journal of Evolutionary Biology 23(9):20042016. https://doi.org/10.1111/j.1420-9101.2010.02071.x

Gharbi, A., Farcy, E., Van Wormhoudt, A., Denis, F. 2016. Response of the carpet shell clam (Ruditapes decussatus) and the Manila clam (Ruditapes philippinarum) to salinity stress. Biologia 71(5):551-562. https://doi.org/10.1515/ biolog-2016-0072

Granovitch, A. I., Maximovich, A. N. 2013. Long-term population dynamics of Littorina obtusata: the spatial structure and impact of trematodes. Hydrobiologia 706(1):91-101. https://doi.org/10.1007/s10750-012-1411-7

Granovitch, A. I., Yagunova, E. B., Maximovich, A. N., Sokolova, I. M. 2009. Elevated female fecundity as a possible compensatory mechanism in response to trematode infestation in populations of Littorina saxatilis (Olivi). International Journal for Parasitology 39(9):1011-1019. https:// doi.org/10.1016/j.ijpara.2009.02.014

Granovitch, A. I., Mikhailova, N. A., Znamenskaya, O., Petrova Yu. A. 2004. Species complex of mollusks of the genus Littorina (Gastropoda: Prosobranchia) from the eastern Murman coast. Zoologicheskij Zhurnal 83(11):1305-1316.

Granovitch, A. I., Maximovich, A. N., Avanesyan, A. V., Starunova, Z. I., Mikhailova, N. A. 2013. Micro-spatial distribution of two sibling periwinkle species across the intertidal indicates hybrdization. Genetica 141(7-9):293-301. https:// doi.org/10.1007/s10709-013-9728-3

Granovitch, A. I. 2016. From host-parasite systems to parasitic systems: Interactions of littoral mollusks of the genus Littorina with their trematode parasites. Biology Bulletin 43(8):776-787. https://doi.org/10.1134/ S1062359016080094

Gunter, G. 1961. Some relations of estuarine organisms to salinity. Limnology and Oceanography 6(2):182-190. https:// doi.org/10.4319/lo.1961.6.2.0182
Hansen, D. V., Rattray, M. 1966. New dimensions in estuary classification. Limnology and Oceanography 11(3):319326. https://doi.org/10.4319/lo.1966.11.3.0319

Hartl, F. U. 1996. Molecular chaperones in cellular protein folding. Nature 381(6583):571-580. https://doi. org/10.1038/381571a0

Hartl, F. U., Bracher, A., Hayer-Hartl, M. 2011. Molecular chaperones in protein folding and proteostasis. $\mathrm{Na}$ ture 475(7356):324-332. https://doi.org/10.1038/nature10317

Hayes, J.D., \& Strange, R. C. 2000. Glutathione S-transferase polymorphisms and their biological consequences. Pharmacology 61(3):154-166. https://doi. org/10.1159/000028396

Honorato, T. B. M., Boni, R., da Silva, P. M., Marques-Santos, L. F. 2017. Effects of salinity on the immune system cells of the tropical sea urchin Echinometra lucunter. Journal of Experimental Marine Biology and Ecology 486:22-31. https://doi.org/10.1016/j.jembe.2016.09.012

Hoy, M., Boese, B. L., Taylor, L., Reusser, D., Rodriguez, R. 2012. Salinity adaptation of the invasive New Zealand mud snail (Potamopyrgus antipodarum) in the Columbia River estuary (Pacific Northwest, USA): physiological and molecular studies. Aquatic Ecology 46(2):249-260. https://doi.org/10.1007/s10452-012-9396-x

Jauzein, C., Donaghy, L., \& Volety, A. K. 2013. Flow cytometric characterization of hemocytes of the sunray venus clam Macrocallista nimbosa and influence of salinity variation. Fish and Shellfish Immunology 35(3):716-724. https://doi. org/10.1016/j.fsi.2013.06.003

Jiang, H., Li, F., Xie, Y., Huang, B., Zhang, J., Zhang, J., ... Xiang, J. 2009. Comparative proteomic profiles of the hepatopancreas in Fenneropenaeus chinensis response to hypoxic stress. Proteomics 9(12):3353-3367. https://doi. org/10.1002/pmic.200800518

Johannesson, K., Rolán-Alvarez, E., \& Erlandsson, J. 1997. Growth rate differences between upper and lower shore ecotypes of the marine snail Littorina saxatilis (Olivi) (Gastropoda). Biological Journal of the Linnean Society 61(2):267-279. https://doi. org/10.1111/j.1095-8312.1997.tb01790.x

Kamradt, M. C., Lu, M., Werner, M. E., Kwan, T., Chen, F., Strohecker, A., ... Duckett, C. S. 2005. The small heat shock protein aB-crystallin is a novel inhibitor of TRAIL-induced apoptosis that suppresses the activation of caspase-3. Journal of Biological Chemistry 280(12):11059-11066.

Khlebovich, V. V., Aladin, N. V. 2010. Factor solyonosti v zhizni zhivotnykh [Salinity factor in animal living]. Vestnik Rossiyskoy Akademii Nauk 80(5-6):527-532.

Kültz, D., Fiol, D., Valkova, N., Gomez-Jimenez, S., Chan, S. Y., Lee, J. 2007. Functional genomics and proteomics of the cellular osmotic stress response in non-model' organisms. Journal of Experimental Biology 210(9):1593-1601. https://doi.org/10.1242/jeb.000141

Kumari, S., nee Sabharwal, V. P., Kushwaha, H. R., Sopory, S. K., Singla-Pareek, S. L., Pareek, A. 2009. Transcriptome map for seedling stage specific salinity stress response indicates a specific set of genes as candidate for saline tolerance in Oryza sativa L. Functional and Integrative Genomics 9(1):109. https://doi.org/10.1007/s10142-008-0088-5

Lemasters, J. J., Holmuhamedov, E. 2006. Voltage-dependent anion channel (VDAC) as mitochondrial governator thinking outside the box. Biochimica et Biophysica Acta (BBA) - Molecular Basis of Disease 1762(2):181-190. https://doi.org/10.1016/j.bbadis.2005.10.006

Li, Y., Zhang, L., Qu, T., Li, L., Zhang, G. 2016. Characterization of oyster voltage-dependent anion channel 2 (VDAC2) suggests its involvement in apoptosis and host defense. 
PLoS One 11(1):e0146049. https://doi.org/10.1371/journal.pone.0146049

Lobov, A. A., Maltseva, A. L., Mikhailova, N. A., Granovitch, A. I. 2015. LOSP: a newly identified sperm protein from Littorina obtusata. Journal of Molluscan Studies 81(4):512-515. https://doi.org/10.1093/mollus/eyv010

Lockwood, B. L., Somero, G. N. 2011. Transcriptomic responses to salinity stress in invasive and native blue mussels (genus Mytilus). Molecular Ecology 20(3):517-529. https:// doi.org/10.1111/j.1365-294X.2010.04973.x

Lushchak, V.I. 2011. Environmentally induced oxidative stress in aquatic animals. Aquatic Toxicology 101(1):1330. https://doi.org/10.1016/j.aquatox.2010.10.006

Maltseva, A. L., Varfolomeeva, M. A., Lobov, A. A., Mikhailova, N.A., Renaud, P.E., Grishankov, A. V., ... Granovitch, A.I. 2016. Measuring physiological similarity of closely related littorinid species: a proteomic insight. Marine Ecology Progress Series 552:177-193. https://doi. org/10.3354/meps11770

Meng, X. L., Dong, Y. W., Dong, S. L., Yu, S. S., Zhou, X. 2011. Mortality of the sea cucumber, Apostichopus japonicus Selenka, exposed to acute salinity decrease and related physiological responses: osmoregulation and heat shock protein expression. Aquaculture 316(1):88-92. https://doi.org/10.1016/j.aquaculture.2011.03.003

Meng, J., Zhu, Q., Zhang, L., Li, C., Li, L., She, Z.... Zhang, G. 2013. Genome and transcriptome analyses provide insight into the euryhaline adaptation mechanism of Crassostrea gigas. PLoS One 8(3):e58563. https://doi. org/10.1371/journal.pone.0058563

Mikhailova, N.A., Gracheva, Y.A., Backeljau, T., Granovitch, A.I. 2009. A potential species-specific molecular marker suggests interspecific hybridization between sibling species Littorina arcana and L. saxatilis (Mollusca, Caenogastropoda) in natural populations. Genetica 137(3):333. https://doi.org/10.1007/s10709-009-9397-4

Morrison, J.F. 1973. 13 Arginine Kinase and Other Invertebrate Guanidino Kinases. The Enzymes 8:457-486. https://doi.org/10.1016/S1874-6047(08)60073-6

Muraeva, O.A., Maltseva, A. L., Mikhailova, N.A., Granovitch, A.l. 2016. Mechanisms of adaption to salinity stress in marine gastropods Littorina saxatilis: a proteomic analysis. Cell and Tissue Biology 10(2):160-169. https://doi.org/10.1134/S1990519X16020085

Oksanen, J. F., Blanchet, G., Friendly, M., Kindt, R., Legendre, P., McGlinn, D., Minchin, P. R., O'Hara, , R. B., Simpson, G. L., Solymos, P., Stevens, M. H. H., Szoecs, E., and Wagner H. 2017. vegan: Community Ecology Package. R package, version 2.4-4. URL: https://CRAN.R-project.org/ package $=$ vegan

Panova, M., Johannesson, K. 2004. Microscale variation in AAT (aspartate aminotransferase) is supported by activity differences between upper and lower shore allozymes of Littorina saxatilis. Marine Biology 144(6):1157-1164. https://doi.org/10.1007/s00227-003-1274-6

Panova, M., Hollander, J., Johannesson, K. 2006. Site-specific genetic divergence in parallel hybrid zones suggests nonallopatric evolution of reproductive barriers. Molecular Ecology 15(13):4021-4031. https://doi.org/10.1111/ j.1365-294X.2006.03067.x

Pierce, S. K. 1982. Invertebrate cell volume control mechanisms: a coordinated use of intracellular amino acids and inorganic ions as osmotic solute. The Biological Bulletin 163(3):405-419. https://doi.org/10.2307/1541452

Plekhanov, A., Smurov, A. O., Podlipaeva, I., Ivanova, L. O., Gudkov, A. V. 2006. Heat shock proteins of freshwater protists and their involvement in adaptation to changes in the environmental salinity. Tsitologiia 48(6):530-534.
Podlipaeva, Y. I., Berger, V. Y. 2012. The effect of environmental salinity on the level of heat shock proteins in gill epithelium of Mytilus edilis L. mussel. Cell and Tissue Biology 6(5):498-502.

Podlipaeva, Y.I., Goodkov, A. V., Berger, V. Y. 2016. Changes in the $70 \mathrm{kDa}$ stress protein content in the course of the Mytilus edulis L. mollusk acclimation to low salinity. Cell and Tissue Biology 10(5):430-434. https://doi. org/10.1134/S1990519X16050114

Quesada, H., Posada, D., Caballero, A., Morán, P., Rolán-Alvarez, E. 2007. Phylogenetic evidence for multiple sympatric ecological diversification in a marine snail. Evolution 61(7):1600-1612. https://doi.org/10.1111/j.15585646.2007.00135.x

R Core Team 2017. R: A language and environment for statistical computing. R Foundation for Statistical Computing, Vienna, Austria.

Ravinet, M., Westram, A., Johannesson, K., Butlin, R., André, C., Panova, M. 2016. Shared and nonshared genomic divergence in parallel ecotypes of Littorina saxatilis at a local scale. Molecular Ecology 25(1):287-305. https://doi. org/10.1111/mec.13332

Redfield, A. C. 1958. The biological control of chemical factors in the environment. American Scientist 46(3):230A-221.

Reid, D.G. 1996. Systematics and evolution of Littorina (No. 164). Ray Society. https://doi.org/10.1017/ S002531540004114X

Robertson, J. D. 1941. The function and metabolism of calcium in the invertebrata. Biological Reviews 16(2):106-133. https://doi.org/10.1111/j.1469-185X.1941.tb01097.x

Rolan-Alvarez, E., Austin, C., Boulding, E. G. 2015. The contribution of the genus Littorina to the field of evolutionary ecology. Oceanography and Marine Biology: an Annual Review 53:157-214. https://doi.org/10.1201/b18733-6

Santa Brígida, A. B., Dos Reis, S. P., Costa, C. D. N. M., Cardoso, C. M. Y., Lima, A. M., de Souza, C. R. B. 2014. Molecular cloning and characterization of a cassava translationally controlled tumor protein gene potentially related to salt stress response. Molecular Biology Reports 41(3):17871797. https://doi.org/10.1007/s11033-014-3028-6

Seveso, D., Montano, S., Strona, G., Orlandi, I., Galli, P., Vai, M. 2013. Exploring the effect of salinity changes on the levels of Hsp60 in the tropical coral Seriatopora caliendrum. Marine Environmental Research 90:96-103. https://doi. org/10.1016/j.marenvres.2013.06.002

Sokolova, I. M., Pörtner, H. O. 2001a. Physiological adaptations to high intertidal life involve improved water conservation abilities and metabolic rate depression in Littorina saxatilis. Marine Ecology Progress Series 224:171-186. https://doi.org/10.3354/meps224171

Sokolova, I., Pörtner, H. O. 2001b. Temperature effects on key metabolic enzymes in Littorina saxatilis and L.obtusata from different latitudes and shore levels. Marine Biology 139(1):113-126. https://doi.org/10.1007/ s002270100557

Sokolova, I. M., Bock, C., Pörtner, H. O. 2000. Resistance to freshwater exposure in White Sea Littorina spp. I: Anaerobic metabolism and energetics. Journal of Comparative Physiology B: Biochemical, Systemic, and Environmental Physiology 170(2):91-103. https://doi.org/10.1007/ s003600050264

Stacklies, W., Redestig, H., Scholz, M., Walther, D., Selbig, J. 2007. pcaMethods - a bioconductor package providing PCA methods for incomplete data. Bioinformatics 23(9):1164-1167. https://doi.org/10.1093/bioinformatics/btm069

Storey, K. B., Lant, B., Anozie, O. O., Storey, J. M. 2013. Metabolic mechanisms for anoxia tolerance and freezing 
survival in the intertidal gastropod, Littorina littorea. Comparative Biochemistry and Physiology Part A: Molecular and Integrative Physiology 165(4):448-459. https://doi. org/10.1016/j.cbpa.2013.03.009

Strange, R. C., Spiteri, M.A., Ramachandran, S., Fryer, A. A. 2001. Glutathione-S-transferase family of enzymes. Mutation Research/Fundamental and Molecular Mechanisms of Mutagenesis 482(1):21-26. https://doi.org/10.1016/ S0027-5107(01)00206-8

Stucchi-Zucchi, A., Salomão, L. C. 1998. The ionic basis of membrane potentials and adaptation to hyposmotic stress in Perna perna, an osmoconforming mollusc. Comparative Biochemistry and Physiology Part A: Molecular and Integrative Physiology 121(2):143-148. https://doi. org/10.1016/S1095-6433(98)10115-0

Suzuki, R. and Shimodaira, H. 2015. pvclust: Hierarchical Clustering with P-Values via Multiscale Bootstrap Resampling. R package version 2.0-0. URL: https://CRAN.Rproject.org/package=pvclust

Tabata, S. 1961. Temporal changes of salinity, temperature, and dissolved oxygen content of the water at Station" P" in the northeast Pacific Ocean, and some of their determining factors. Journal of the Fisheries Board of Canada 18(6):1073-1124. https://doi.org/10.1139/f61-066

Tomanek, L., and Zuzow, M. J. 2010. The proteomic response of the mussel congeners Mytilus galloprovincialis and $M$. trossulus to acute heat stress: implications for thermal tolerance limits and metabolic costs of thermal stress. Journal of Experimental Biology 213(20):35593574. https://doi.org/10.1242/jeb.041228

Tomanek, L., Zuzow, M. J., Hitt, L., Serafini, L., Valenzuela, J. J. 2012. Proteomics of hyposaline stress in blue mussel congeners (genus Mytilus): implications for biogeographic range limits in response to climate change. Journal of Experimental Biology 215(22):3905-3916. https://doi. org/10.1242/jeb.076448

Tsujimoto, Y., Shimizu, S. 2002. The voltage-dependent anion channel: an essential player in apoptosis. Biochimie 84(2):187-193. https://doi.org/10.1016/S03009084(02)01370-6

Tuynder, M., Fiucci, G., Prieur, S., Lespagnol, A., Géant, A., Beaucourt, S., ... Moras, D. 2004. Translationally controlled tumor protein is a target of tumor reversion. Proceedings of the National Academy of Sciences of the United States of America 101(43):15364-15369. https:// doi.org/10.1073/pnas.0406776101

Vincent, D., Ergül, A., Bohlman, M.C., Tattersall, E. A., Tillett, R. L., Wheatley, M. D., ... Schooley, D. A. 2007. Proteomic analysis reveals differences between Vitis vinifera L. Cv. Chardonnay and cv. Cabernet Sauvignon and their responses to water deficit and salinity. Journal of Experi- mental Botany 58(7):1873-1892. https://doi.org/10.1093/ jxb/erm012

Wang, F., Yang, H., Gao, F., Liu, G. 2008. Effects of acute temperature or salinity stress on the immune response in sea cucumber, Apostichopus japonicus. Comparative Biochemistry and Physiology Part A: Molecular \& Integrative Physiology 151(4):491-498. https://doi.org/10.1016/j. cbpa.2008.06.024

Wang YM. 2013. The ecology of Singapore littorinids Echinolittorina malaccana and E. vidua in relation to thermal stress. PhD Thesis. Nanyang.

Warner, J. R. 1999. The economics of ribosome biosynthesis in yeast. Trends in Biochemical Sciences 24(11):437-440. https://doi.org/10.1016/S0968-0004(99)01460-7

Weber, C., Guigon, G., Bouchier, C., Frangeul, L., Moreira, S. Sismeiro, O., ... Guillén, N. 2006. Stress by heat shock induces massive down regulation of genes and allows differential allelic expression of the Gal/GalNAc lectin in Entamoeba histolytica. Eukaryotic Cell 5(5):871-875. https://doi.org/10.1128/EC.5.5.871-875.2006

Wen, G. Q., Cai, L., Liu, Z., Li, D. K., Luo, Q., Li, X. F., ... Yang, Y. 2011. Arabidopsis thaliana VDAC2 involvement in salt stress response pathway. African Journal of Biotechnology 10(55):11588-11593. https://doi.org/10.4238/2015. December.1.1

Westram, A. M., Galindo, J., Alm Rosenblad, M., Grahame, J. W., Panova, M., Butlin, R. K. 2014. Do the same genes underlie parallel phenotypic divergence in different Littorina saxatilis populations? Molecular Ecology 23(18):46034616. https://doi.org/10.1111/mec.12883

Wickham, H., 2009. ggplot2: Elegant Graphics for Data Analysis Springer-Verlag. New York.

Woo, S., Yum, S., Kim, Y.T., Suh, S. J., Kim, H. C., Lee, J., ... Lee, T. K. 2006. Thermal and organic chemical stress responsive genes in soft coral, Scleronephthya gracillimum. Molecular and Cellular Toxicology 2:170-175.

Yan, L., Su, J., Wang, Z., Yan, X., Yu, R., Ma, P., ... Du, J. 2017. Transcriptomic analysis of Crassostrea sikamea $\times$ Crassostrea angulata hybrids in response to low salinity stress. PLoS One 12(2):e0171483. https://doi.org/10.1371/journal. pone. 0171483

Yang, C. Y., Sierp, M. T., Abbott, C. A., Li, Y., Qin, J. G. 2016. Responses to thermal and salinity stress in wild and farmed Pacific oysters Crassostrea gigas. Comparative Biochemistry and Physiology Part A: Molecular \& Integrative Physiology 201:22-29. https://doi.org/10.1016/j. cbpa.2016.06.024

Zhao, X., Yu, H., Kong, L., Li, Q. 2012. Transcriptomic responses to salinity stress in the Pacific oyster Crassostrea gigas. PLoS One 7(9):e46244. https://doi.org/10.1371/journal. pone.0046244

\section{Supplementary materials are available on-line at https://biocomm.spbu.ru. https://doi.org/10.21638/11701/spbu03.2017.306}

